\title{
Assembling Sustainable Territories Space, Subjects, Objects, and Expertise in Seafood Certification
}

Vandergeest, Peter; Ponte, Stefano; Bush, Simon

Document Version

Accepted author manuscript

Published in:

Environment and Planning $A$

DOI:

$10.1177 / 0308518 \times 15599297$

Publication date:

2015

License

Unspecified

Citation for published version (APA):

Vandergeest, P., Ponte, S., \& Bush, S. (2015). Assembling Sustainable Territories: Space, Subjects, Objects, and Expertise in Seafood Certification. Environment and Planning A, 47(9), 1907-1925.

https://doi.org/10.1177/0308518X15599297

Link to publication in CBS Research Portal

\section{General rights}

Copyright and moral rights for the publications made accessible in the public portal are retained by the authors and/or other copyright owners and it is a condition of accessing publications that users recognise and abide by the legal requirements associated with these rights.

Take down policy

If you believe that this document breaches copyright please contact us (research.lib@cbs.dk) providing details, and we will remove access to the work immediately and investigate your claim. 


\section{Assembling Sustainable Territories: Space, Subjects, Objects, and Expertise in Seafood Certification}

\section{Peter Vandergeest, Stefano Ponte, and Simon Bush}

Journal article (Post print version)

CITE: Assembling Sustainable Territories: Space, Subjects, Objects, and Expertise in Seafood Certification. / Vandergeest, Peter; Ponte, Stefano; Bush, Simon. In: Environment and Planning A, Vol. 47, No. 9, 2015, p. 1907-1925.

DOl: https://doi.org/10.1177/0308518K15599297

Uploaded to Research@CBS: December २०16 


\section{Assembling Sustainable Territories: Space, Subjects, Objects and Expertise in Seafood Certification}

Abstract. In this article we show how certification assembles 'sustainable' territories through a complex layering of regulatory authority in which both government and non-government entities claim rule-making authority, sometimes working together, sometimes in parallel, sometimes competitively. We argue that territorialisation is accomplished not just through (re)defining bounded space, but more broadly through the assembling of four elements: space, subjects, objects, and expertise. Through the analysis of four case studies of sustainability certification in seafood, we conclude that assembling sustainability territories does not necessarily lead to a 'green grab', and that while some state agencies have been suspicious of sustainability certification, others have embraced it or even used it to extend their sovereignty. Finally, we call for more nuanced understandings of sustainability certification as made up of multiple logics beyond the market.

Keywords: sustainability certification, territory, green grabbing, seafood

\section{Introduction}

Sustainability certifications have drawn increasing attention from scholars interested in how they are transforming the management and extraction of natural resources. Scholarship has often focused on how sustainability certification brings new non-government actors into resource management, including both industry actors and non-profit organisations (e.g. Eden, 2009; Foley and Hébert, 2013; Ha et al., 2012; Hatanaka, 2010; Klooster, 2005; Mutersbaugh, 2005; Ponte, 
2008; Vandergeest and Unno, 2012) In this article we will show how private or non-government certification works in practice through diverse kinds of government regulation. We make this point through a careful examination of how sustainability certification assembles and remakes territories. Our focus on territorialisation will reveal how transnational sustainability certification creates layers of regulatory authority in which both government and non-government entities claim rule-making authority, sometimes working together, sometimes in parallel, sometimes competitively.

This article builds on the emerging critique of what is referred to as 'neo-liberal' nongovernment or market-oriented environmental governance (e.g. Foley and Hébert, 2013; Higgins et al., 2008; Klooster, 2005; Konefal, 2013; Mutersbaugh and Lyon, 2010), or more recently 'green grabbing' (Corson et al., 2013; Fairhead et al., 2012; MacDonald, 2013). This term refers to both the history of state 'appropriation of land and resources for environmental ends' (Fairhead et al., 2012: 237) and the emergence of new kinds of private commodification and markets for nature. Green grabbing describes how state institutions are aligning with market logics to create and commodify new natures through new forms of environmental conservation, a process that in turn contributes to new forms of capital accumulation (Corson et al., 2013; MacDonald, 2013: 48). In short, the 'grab' is the enclosure of land and other natural resources for the purpose of turning them into forms of nature that can be sold. The green grabbing metaphor is used to illustrate how market logics have become dominant in the field of environmental conservation, displacing a prior logic based on the idea that a Keynesian state should act to protect the environment (Corson et al., 2013:7). The literature on green grabbing acknowledges that state territorialisation continues to be essential to market environmentalism because of its role in creating property rights and thus in determining who has legitimate access to resources (Ramirez 
Cover, 2013:151). Green grabbing is thus viewed as the means by which non-state actors reshape state territorialisation to further enable the commodification of nature.

We argue that the relationship between state action, market logics and territorialisation in environmental governance bears closer examination. We do this by analysing how 'sustainable territories' are assembled through the certification of sustainable seafood. Sustainability certification differs from state authority in that rules, enforcement and monitoring activities are market-oriented and often private. Certification is intended to create market values and manage market risks through the use of sustainability labels. The label 'fixes' (Fairhead et al., 2012: 38) a variety of spaces into one commodified sustainable form, by fixing ecological (and social) problems and/or fixing this repair symbolically into an ecolabel or logo that has exchange and brand value. Although sustainability certification is distinct from the market-oriented conservation programs that are often the focus of the green grabbing literature, it can be understood as a form of green grabbing in how it has been presented by its proponents as an ideal mechanism for selling nature to save it, and in how it can be seen as the ultimate expression of a market logic in environmental governance. More broadly, sustainability certification provides a means by which non-state entities (Cashore et al 2004) claim the authority to make rules (Corson 2011, Havice and Iles 2015) with respect to environmental and social processes in specified spaces, and use market access to reward producers who can demonstrate adherence to these rules. Our framework for understanding how sustainable territories are assembled for the case of certification can thus help us better understand green grabbing in market-oriented conservation as well.

In this article, however, we question the narrow focus on the creation of market value by showing that there are instead multiple logics shaping the use and outcomes of sustainability 
certifications. More specifically, we show that sustainable territories are assembled through a variety of mechanisms and a complex layering of state and private authority. In many cases, state agencies are reluctant to cede authority to non-state entities, and in these situations, private- and state-territorialisations can be highly competitive and controversial (Foley and Hébert, 2013; Vandergeest and Unno, 2012). In other cases, state agencies welcome the opportunity to 'outsource' certain components of regulatory authority, or see certification as a way to enhance their power and funding for reasons that have little to do with commodification. Building on these debates we argue that these complex and hybrid territorialisations are representative of the political and discursive geographies of control over production, trade and public regulation. Sustainability certification therefore is not just green grabbing by private entities with the cooperation of state agencies aligning themselves with market logics, but an interaction between public and private authorities working through multiple logics.

Our understanding of territorialisation draws on political ecology scholarship, which defines it as a process of creating a territory through the delineation of boundaries, and claiming the authority to control what people do inside of these boundaries through enforceable rules (Vandergeest and Peluso, 1995). 'Control' usually refers to controlling how people use and manage ecologies or natural resources - forests, fisheries, land, animals and so on. Insofar as territorialisation involves a claim over the authority to determine who controls land and resources, it is also a kind of state-making (Corson, 2011; Sikor and Lund, 2009). By coopting processes of state territorialisation, non-state entities can expand control and authority over natural resources and people, as demonstrated by scholarship on so-called land and green grabbing (Corson, 2011; Ramirez Cover, 2013). However, the cooption and control of resources can also be facilitated through (global) networks of non-state entities defining boundaries and embedding processes of 
value creation in, out and across state territories (e.g. Bridge 2011; Bowen 2011; Vandergeest and Unno 2012).

In this article we interpret the concept of territorialisation in the context of sustainability certification as the specific interaction between state and non-state actors in assembling 'sustainable territories'. This is a process that draws on existing spaces and authority but also reshapes their boundaries and connections, sometimes adding new elements and dimensions. A sustainable territory is thus an 'effect' of networked relations (Painter, 2010: 1093) among the elements that constitute certification. To explore this process, we focus on how territorialisation is accomplished through the assembling of four elements: space, subjects, objects, and expertise. First, sustainable territories re-define bounded spaces for the purpose of controlling activities; these spaces, which may be contiguous or topographically distant (Bear and Eden, 2008), are connected to each other through processes of certification. Second, sustainable territories are created through the identification of subjects (Peluso and Vandergeest, 2001) who are allocated use rights and the authority to manage objects of concern within the rules set out by state or private authorities. Third, they specify objects of concern (and simultaneously objects of nonconcern) that are either fixed within spatially defined spaces or move across spatial boundaries to areas outside it. Finally, sustainable territories are defined by expertise, which we understand in terms of a bundle of codified and concentrated knowledges (Mitchell, 2002), and the 'experts' who have the exclusive capacity and qualifications to create or apply these knowledges, produce the rules that define the central objects of concern, and thus the ecologies that need to be protected.

Building on themes in actor network theory, assembling sustainable territories is based on the 'net-work' of symbolically connecting actors within bounded spaces that are topographically 
distant, and in doing so establish mechanisms of control over those spaces (Murdoch 1998). But it also involves active 'boundary work' in defining space, subjects, objects and expertise - work that redefines, stretches and fixes boundaries, or makes them more or less porous. In science and technology studies the term boundary work is widely used to describe how science attempts to maintain itself as distinct from politics, a process we also see through the making of technical expertise. Boundary work can also be applied to the ways that spaces are defined and connected with each other, objects and subjects are included/ excluded, different kinds of expertise are accepted or not, and rules regulating movement across boundaries are set. What boundaries are contested, how, and by whom? What are the consequences of these actions? How do boundaries set limits on the production of a sustainable territory? At what point does boundary work undermine the legitimacy (and value) of a label? In this article we explore these questions by showing how assembling sustainability territories works through the making of complex, contested, and unstable boundaries — not just bounded and networked spaces, but also objects, subjects and expertise.

Two sectors that offer contrasting perspectives on how sustainable territories are produced through sustainability certification are fisheries and aquaculture. In fisheries, both the resource and fish stocks are mobile and often (but not always) crossing political borders. By contrast aquaculture is made up of sedentary production systems, and production inputs are part of global flows of feed and seed and pharmaceutical products. However, fish and fish products from both sectors are traded as seafood, together constituting the most globally traded agro-food commodity by volume, with half of the imports to the global North coming from the global South (FAO, 2012). And in addition, many major buyers in the global North (including most major supermarket chains) are now requiring sustainability certification of most or all seafood as part of 
their public commitment to sustainability (Bush et al., 2013). Against this backdrop, fisheries and aquaculture are highly illustrative for contrasting combinations of state and non-state regulation that create different sustainable territories based on diverse assemblages of space, subjects, objects, and expertise.

We now turn to a short review of the emergence of sustainability certification and the constituent roles of public and private authority, before elaborating our framework of assembling sustainable territories through space, subjects, objects, and expertise. This is followed by the presentation of two fisheries and two aquaculture case studies in which we apply our framework. We conclude the article with a collective discussion of these cases and reflect on how they inform the broader literature on market-oriented conservation or green grabbing, as well as future research needs.

\section{Sustainability Certification, Markets and the State}

Sustainability certification can be understood as a set of interlinked governance practices that minimally includes: 1) setting standards for ecological and social interactions; 2) auditing compliance with these standards; 3) assigning labels or logos to products and enterprises which meet the standards; and 4) creating institutions to implement these activities (Hatanaka et al., 2005; Mutersbaugh, 2005). In so-called first-party certification, standards are audited by suppliers themselves; in second-party certification, standards are audited by professionals hired by buyers or industry associations; in third-party certification (what we mean by 'certification' in this article), standards are audited by independent certifiers (Hatanaka et al., 2005). Certification is not necessarily a non-government or market-oriented activity; states also certify entities as sustainable, safe and so on, and these certifications are not necessarily tied to labels that acquire 
exchange value. Nevertheless, most scholarship on sustainability certification has focused on the emergence of so-called 'non-state market-driven' environmental governance, exemplified initially by the Forestry Stewardship Council (Cashore et al., 2004). But this type of certification has now spread and proliferated, to include hundreds of non-state institutions involved in certifying activities ranging from forestry and fisheries to the production of many other agro-food items, such as palm oil, tea, sugar, cocoa and coffee.

The emergence of transnational and non-governmental sustainability certification is described by many environmental NGOs, as well as academics (Auld et al., 2009; Cashore et al., 2004), through a standard tripartite narrative. First, the public expects that governments should act on behalf of our common interest in protecting the environment; however, state resource agencies like forestry departments, agriculture departments, and fisheries departments are more concerned with increasing extraction, as their power and influence is directly tied to the value of the resource they administer, while conservation agencies in government are deemed ineffective in the face of business interests. Second, the state's ability to regulate effectively has been affected by neoliberal policies, which have eroded state monitoring capacity, weakened regulations, and placed constraints on action through free trade agreements. And third, global level agencies such as the FAO suffer the same weaknesses, with critics arguing that it is too influenced by member-state resource agencies to be able to take serious action promoting sustainability or environmental protection.

This narrative emerged in large part in response to the experience of environmental groups with tropical deforestation (Cashore et al., 2004), but when generalised to other resource sectors, its historical accuracy is open to question. For example, certification initiatives for aquaculture can be traced back to the 1990s when industry players sought to counteract increasing 
government regulation through alternative programs promoting industry self-regulation (Béné, 2005). Moreover, this account underplays the many important ways that states contribute to shaping and facilitating transnational sustainability certification (e.g. Gulbrandsen, 2013). Nevertheless, this failure-of-the-state narrative has been used to justify the way that private actors are inserting themselves into existing regulatory activities that were previously considered the domain of government authority.

Proponents of sustainability certification also justify private authority through the argument that they are in a position to take advantage of the leverage that big branded retail corporations exert in global value chains. Many large environmental groups believe they can be more effective in leveraging large corporate buyers than in lobbying states (Konefal, 2010, 2013); and perhaps more cynically, they can also generate financial benefits if they partner with corporate buyers in forging 'sustainable value chains'. The leverage of these groups over buyers is based on the perception that retailers share responsibility for the conditions under which the products they buy are produced, and that consumers will reward them for improving these conditions. Retailers and branded processors are exposed to reputational risk, since their brand value and/or market capitalisation are susceptible to scandals related to unsafe or inequitable working conditions, or environmentally unsustainable production practices of the products they sell. But from a corporate perspective, sustainability certification also builds brand value and corporate reputation, can be a form of risk insurance, and can contribute to building traceability and tightening control over suppliers (Gibbon and Ponte, 2005).

In relation to seafood, most major international environmental organisations directly or indirectly support sustainability certification, even those that are not directly involved in setting up these programs. For example, in the UK, Canada, the United States and Western Europe, 
supermarkets have been strongly influenced by Greenpeace's annual ranking of supermarkets performance with respect to sustainable seafood from both fisheries and aquaculture, in most cases responding with a promise of sourcing from certified sustainable sources. Although there are over 30 different schemes targeting specific production systems, species and issues (e.g. Parkes et al., 2010), four broad-based certification schemes are currently dominant in seafood. In capture fisheries, the Marine Stewardship Council (MSC) occupies a quasi-monopolistic position in the sustainability certification market (Ponte, 2012). In aquaculture, three initiatives dominate the market for sustainability certification: the US-based industry organisation Global Aquaculture Alliance (GAA); the Aquaculture Stewardship Council (ASC), which was launched recently by the WWF and seafood buyers in Europe, and is just beginning to carry out certification; and GlobalGAP, a European retailer network with a program for aquaculture certification that includes environmental and social standards. These four initiatives have become major players in transnational sustainability governance of fisheries and aquaculture, as most major buyers in Europe and North America have committed to sourcing all or most of their seafood from certified sources. In addition to these broader programmes, organic certification has also become important for some species and places.

\section{Spaces, Subjects, Objects and Expertise}

Sustainability certification (re)assembles spaces, objects, subjects and expertise into sustainable territories in new configurations, often adding new elements and connections but also drawing on existing elements while remaking their boundaries. In capture fisheries, sustainability certification defines space by mapping relevant fishing zones and, less often, related conservation areas (Bear and Eden, 2008). It also (re)defines subjects: these include subjects whose behavior 
needs to be regulated, such as fishers, traders, processors, or government agencies whose management practices are subjected to assessment and surveillance; and the subjects who are the paying 'clients' of certification - in capture fisheries, these are often collective agents, such as fishery associations or government departments (Foley, 2012a). Sustainability certification also specifies objects of concern, including not only the species that can be caught and marketed through a sustainability label, but also other objects that are related to (or impacted by) the production process, such as fishing gear, by-catch, birds, turtles, dolphins, or broader marine ecosystems. The materiality of these objects, and the marine environment in which they operate, render areal boundaries problematic and fluid due to the movements of fish, vessels, and currents (Bear and Eden, 2008). Finally, certification shapes the boundaries of accepted expertise, including that of trained auditors, accredited certification bodies, and other relevant experts who codify, assess, monitor, and document stocks, eco-systems and fishery management procedures.

In sustainability certification of aquaculture, space may appear at first glance to be defined as the farm territory, but boundaries are often not clearly demarcated, for example, when aquaculture takes place in cages or in pond systems that are open to the surrounding environment, or when buffer zones are required. The spatial extent of aquaculture may also be demarcated at larger spatial scales, such as 'aqua-parks' (Brummett, 2013). As in the case of fisheries, these topographically dispersed spaces are symbolically connected through certification. Subjects usually include farmers, but can also incorporate farmer associations, processing companies and less often, government agencies. Sustainability objects in aquaculture include not only the farmed fish, but also feed, chemicals, water, coastal ecologies, species or habitats defined as threatened or endangered, workers, and adjacent residents or communities (Bush et al., 2010; Vandergeest, 2007). Expertise is framed in similar ways as fisheries. The specific knowledge used in 
aquaculture varies by species in some standards, but includes indicators covering production practices related to disease, effluent, feed and seed.

To examine the boundary work through which sustainability territories in fisheries and aquaculture are assembled, we next examine four cases in some detail, based on earlier and ongoing research. We have selected these cases specifically to cover four typologies of variation in scale and in the kinds of applicable property rights, and to illustrate the distinct tensions and instabilities produced by sustainability certification. The first case examines private aquaculture on individual farms, and draws from the case of private farm-level certification by GAA and ASC, and public certification against the Good Aquaculture Practice (GAP) standards in Thailand. The second focuses on groups of aquaculture farmers exploiting common pool resources, through the case of organic group certification of shrimp production in Vietnam. The third focuses on exploitation of a public sovereign capture fishery within national jurisdictions, using the case of the MSC-certified South African hake fishery. And the fourth looks at capture fisheries operating in transnational jurisdictions, using the case of MSC-certified tuna fishery in the waters of the Parties of the Nauru Agreement, Pacific Ocean.

\section{Four case studies}

\subsection{Certified sustainable shrimp farming in Thailand}

\section{Background}

Thailand has been among the leading exporters of cultured shrimp, with most shrimp produced by the approximately 20,000 small and medium-sized grow-out farms (where shrimp are grown from post-larvae or juvenile to market-ready maturity), although corporate farms are also 
significant. The industry also includes hatcheries and large seafood processing plants (Lebel et al., 2010) of which the largest are agro-food conglomerates with transnational operations. It is the processing companies who need to address buyer demands for certification by finding ways of sourcing or producing certified shrimp. At the time of writing, buyers in the United States were requiring ACC certification, while the ASC had not yet started actual certification with its recently finalised standards for shrimp.

The Department of Fisheries in Thailand is the key government agency mandated to regulate shrimp farming. Almost all of the Department's efforts are now devoted to its own 'Good Aquaculture Practices' (GAP) certification program, which it originally launched in $2002 .{ }^{1}$ The GAP was initially focused on traceability and anti-biotic residue testing, but in an effort to obtain international recognition, the government issued a new 'GAP 7401-2009' in 2009 (hereafter the 'new GAP'), which added environmental and social criteria. Implementation was also restructured so that that the Department could claim it adhered to ISO and FAO aquaculture certification guidelines. Staff at the Department of Fisheries have indicated that the new GAP will soon be required for farms producing shrimp for export.

(Re)defining space, subject, object and expertise through boundary work

The new GAP, ACC, and ASC certifications are instruments of sustainability territorialization. They all apply their standards to the space of the farm, as defined by stateadministered land codes. They thus require farms to be registered and farmers to have appropriate

\footnotetext{
${ }^{1}$ According to Dr. Waraporn Prompoj of the Department of Fisheries. See slides prepared for a lecture entitled 'Thailand Experience on Aquaculture Certification', presented at the Workshop on Aquaculture Certification in Asia: Status, challenges, opportunities \& way forward (Ho Chi Minh City, Vietnam), available from authors. See also the Department of Fisheries website:

http://www.fisheries.go.th/dof/en/index.php?option=com content\&view=article\&id=5\&Itemid=8. Accessed February 13, 2014.
} 
land right documents. The main subject is defined as 'the farmer' or 'the farm manager'. In practice, subject formation is often more complex. Because it is the processor who needs to find certified shrimp, they have been active in helping farms become certified under groupcertification provisions in the ACC standards. ${ }^{2}$ Thus the ACC's list of certified shrimp farms in Thailand shows that many are certified as groups sponsored by processing companies; in these situations the client is the processor. ${ }^{3}$ The new GAP in Thailand similarly specifies that farms can apply to be certified either individually or as groups.

The ACC, ASC, and new GAP include multiple standards defining and bounding objects of concern - including shrimp production, but also other objects that are not located within the territory of the farm. For example, many critics of shrimp farming have highlighted the inefficiencies of using fishery products in shrimp feed, and there is considerable controversy about the sustainability of the fisheries that supply raw materials for the feed, as well as whether these fish might be better directed to direct human consumption (e.g. Naylor et al., 2009). In response, the ACC requires that farmers obtain their feed from suppliers providing reliable information on the protein, fishmeal, and fish oil content in the feed. But the ACC also limits the responsibility of farmers by not directly specifying any sustainability requirements for the fisheries supplying feed manufacturers. In contrast, the ASC will require that shrimp feed be chain of custody- certified by schemes that are compliant with one of a number of international organisations (e.g. ISEAL, ISO, FAO).

\footnotetext{
${ }^{2}$ See http://www.gaalliance.org/certfication/. Accessed 6 February 2014.

3 Including Thai Union, Thai Royal, Aquapool, Seafresh, Okeanos, East Asia, and Good Luck. See http://www.bestaquaculturepractices.org/index.php?option=com content\&task=view\&id=121\&Itemid=104.

Accessed 6 February 2014.
} 
Fauna and flora in the vicinity of the farm, but typically outside its spatial boundaries, are also cited as objects of concern in all three standards. The ACC defines biodiversity, local crustacean and fish gene pools, and wildlife as concerns, and addresses these through requiring on-farm management practices regarding escapees, compliance with government regulations regarding non-native species and GMOs, and the management of interaction with wildlife. The standards for the new GAP are similar to those of the ACC in identifying flora and fauna as objects of concern. The ASC standards, however, add many objects that are not included in the ACC standards, for example, endangered species, wildlife corridors, coastal barriers, riparian buffers, and native vegetation. However, because the unit of certification remains the individual farm, these standards cannot and do not address the cumulative impacts on these objects of the many hundreds of farms that are often contiguously located. Moreover, the lack of state processes for defining these objects could lead to considerable difficulty in translating these standards into application to specific farms.

What is notable about both the ASC and the ACC is the prominence of 'social' standards-a response to intense criticisms of the social impacts of shrimp farming (Béné, 2005: 590-91). All three certification schemes identify the 'community' as an object of concern, and include a series of standards specifying that farms should not deny local communities access to natural resources, and that farms should have good relations with 'local communities'. Neither the ACC nor the new GAP define this object, while the ASC includes a very general definition of 'community' in a footnote. The ACC's implementation instructions state that evaluators should select local people to interview regarding this standard, while the ASC will require a much more complex 'participatory Social Impact Assessment'. 
When these standards are put into practice, the 'community' is often translated as referring to local government. In Thailand, the most effective government unit for regulating shrimp farming for social impacts has in fact not been the Department of Fisheries, but the Sub-district Administrative Organisation (SAO). Local residents who are not happy with the actions of shrimp farmers have a variety of actions that they can take (Vandergeest, 2007), but the most important has been to ask the SAO to take action (not always with satisfactory results). The SAO in effect acts as the community, while more broadly, local processes for resolving conflicts are key to the ability of the farm to meet the social standards defined by the GAP and ACC.

With respect to expertise, like most certification schemes, all three certification schemes require inspections to be done by accredited auditors. The ACC mandates that auditors must be trained by the ACC in one of their frequent courses. Under the new GAP, the Department of Fisheries is also planning to accredit private certification bodies to carry out the inspections. Neither the ACC nor the GAP requires specific expertise in the production of information that is to be inspected, in contrast with the ASC standards, which require the farmer to have a Biodiversity-inclusive Environmental Impact Assessment (BEIA) done by a nationally-accredited body or by a team of qualified environmental scientists, biologists, and ecologists. The three certification schemes all position local people as knowledgeable with respect to providing information to auditors concerning social standards. However, they were excluded from providing any information and thus from participating in expertise in relation to the many technical standards concerning farm operation, biodiversity and more.

Assembling a sustainability territory: dynamics and outcomes

\subsection{Certified organic shrimp farming in Vietnam}




\section{Background}

The organic shrimp farming project in Ca Mau province in Vietnam has been the subject of considerable debate among environment and development organisations, as well as numerous academic studies (Ha, 2012; Omoto, 2012). The project used Naturland standards, ${ }^{4}$ audited by the Institute for Marketecology (IMO). In 2012, organic certification was taken over by SNV (the Netherlands development agency) and IUCN, with a goal of expanding it into a program to create an 'organic coast'. ${ }^{5}$ In a separate project in the area, the consultancy company Blueyou has created a branded shrimp product (Selva Shrimp) in which shrimp farmer groups are assessed against the new ASC standards. ${ }^{6}$ Our account will focus on the Naturland organic shrimp project before 2012 .

(Re)defining space, subject, object and expertise through boundary work

The initial impetus for the certification came from how these shrimp farms were located in a mangrove area under the jurisdiction of a state owned forestry company, LNT184 (Omoto, 2012:63). LNT184 was established in 1987 to recover mangroves damaged by herbicide applications during the Indochina war. At the same time, settlers who were moved into the area by the government after the war took up forest-based aquaculture, shifting to shrimp during the 1990s. For LNT184, organic certification provided an indirect means for controlling these farmers and stopping further reduction of the mangrove area. The key standard was thus a

\footnotetext{
${ }^{4}$ Naturland standards for aquaculture available at http://www.naturland.de/standards.html\#c1855 (accessed 7 February 2014).

${ }^{5}$ See http://www.snvworld.org/en/redd/news/snv-redd-blog/organic-shrimp-certification-a-new-approach-to-pes.

${ }^{6}$ See http://www.blueyou.com/page/Programmes/Selva Shrimp. A critique by the Mangrove Action Project is available at http://mangroveactionproject.org/monterey-bay-aquarium-seafood-watch-retract-the-best-choice-ratingfor-asc-selva-shrimp/. All websites accessed 21 February 2014.
} 
requirement that certified individual farms had to have 50 percent of the farm under mangrove cover.

Certification in this case was based on a complex nesting of various government-defined spaces. The first was the project area (Ha et al., 2012), which included 3,190 hectares of mangroves, and 2,879 hectares of shrimp farms (Omoto, 2012). The second was the approximately 800 certified farms (Ha et al., 2012), while the third was the assessed mangrove cover in each farm. From the perspective of the state agencies, farm boundaries were based on contracts issued by the state forestry company called 'green books', which were based on a national policy for allocating forest land to households subject to conditions regarding forest and land management (Ha et al., 2012: 188-89). But, for the purpose of auditing, Naturland standards sidestepped these legal documents and re-defined the boundaries of the farming unit through practice, that is, as 'a clearly marked managing sphere on which distinctly separate records are kept for inspection and documentation.'

The definition of subjects was similarly complex. The manager of the broader project area was formally the forestry company, but its participation was marginal. For the individual farms, Naturland provided another explicit definition: 'The manager is the natural person or legal entity running a farm independently and responsibly (farm manager)'. Although (responsible) shrimp farmers were the subjects for the purpose of auditing, the client was a management board, who paid IMO for the inspection service. IMO did not provide auditing reports to farmers directly, instead it provided information on the certification status of individual farms to the intermediaries who purchased shrimp from the farmers, and these intermediaries were supposed to pass on this information to farmers. Omoto's (2012) survey showed that 25 of 70 farmers were misinformed 
about their certification status, with most believing they were certified when they were either suspended or not yet actually certified.

The central object of concern in this certification was the extent of mangrove cover. Farms could not be certified unless they met the Naturland standard that 50 percent of the farm area was under mangrove cover, thus defining a boundary within the farm specifying the maximum space available for actual shrimp farming. About half of the 54 certified or previously certified farmers in Omoto's survey reported that they were required to increase the area of the farm under mangroves, using seedlings provided by LNT 184 (Omoto, 2012:81). Other objects of concern listed in the standards included the use of native shrimp species; water quality, stocking densities; prohibited antibiotics and artificial feed; employee working conditions and housing; and local fishers' access to open water. Potential objects that were excluded from the standards included the quality of the mangrove forest (less easily monitored and assessed) and the broader ecology of the project area - most importantly, the overall percentage of mangrove cover. Overall mangrove was excluded by virtue of using individual farms as the unit of certification. The exclusion was inconsistent with provincial government regulations governing the green book contracts - under which farms with an area of less than 3 ha needed to have forest cover of at least 40 percent; farms sized between 3 and 5 ha, at least 50 percent; and those larger than 5 ha, at least 60 percent. According to IMO staff (Ha et al., 2012:636), 19 small farms which were in compliance with the government's 40 percent standard were not certified in 2009 because audits showed that they did not comply with Naturland's 50 percent standard. Farmers challenged the boundary work that defined the farm as the unit for assessing sustainability, and that excluded overall mangrove cover, by arguing that mangrove cover should be assessed collectively, so that 
the lower mangrove cover on small farms could be compensated by higher mangrove cover on larger farms (Ha et al., 2012:636).

In relation to expertise, Naturland inserted itself into coastal landscape management as the expert body that could define, measure and set conditions for change towards sustainability in the project area, overriding provincial government regulations and farmer arguments that sustainability should be measured at the collective rather than individual farm scale. In addition, only trained auditors employed by IMO could inspect farms and assess their compliance with the Naturland standards. Farmers were not only unable to provide input on what constituted sustainable management, but also not informed directly of the results of inspections on their own farms.

Assembling a sustainability territory: dynamics and outcomes

\subsection{MSC certification of hake in South Africa}

\section{Background}

Since its formation in 1997, the Marine Stewardship Council (MSC) has established itself as the dominant sustainability certification system in capture fisheries, and single-handedly created a commodity called 'sustainable fish' which it has brought into mainstream retail (Ponte, 2008; 2012). South African hake was one of the first large fisheries to be certified by MSC, in April 2004. It was subsequently re-certified in March 2010. The MSC standards are based on three principles (which are elaborated through a series of criteria): the status of the target fish stock; the impact of the fishery on the ecosystem; and the performance of the fishery management system. 
The South African hake fishery began in the 1890s with the deployment of deep-sea trawlers. It was by and large unregulated by the state until after the establishment of an Exclusive Economic Zone (EEZ) in 1977. In 1978 the government agency Marine and Coastal Management (MCM) began to assign annual total allowable catch (TAC) quotas and individual (non-tradable) quotas to fishing companies. At the time of certification the fishery was organised into four sectors: deep-sea trawl, in-shore trawl, longlining, and handlining.

(Re)defining space, subject, object and expertise through boundary work

The space of the certified South African hake fishery is defined territorially by the South African EEZ zone. Thus, MSC certification has not changed the state-defined boundary of the fishery. However, this boundary is porous, as the hake migrate seasonally into Namibian waters, where the fishery is regulated by Namibian fishery authorities and where hake is caught by trawlers often managed by the same companies that catch it in South African waters. Nevertheless, in Namibia the fishery is not certified sustainable. In other words, the fish stock moves across national boundaries, but its sustainability is 'fixed' exclusively to the national space of South Africa's EEZ.

The main subjects for the 2004 certification were the fishing companies members of the South African Deep-Sea Trawling Industry Association (SADSTIA). SADSTIA was the formal client, and the overall cost of MSC certification was paid by its members in proportion to their government-allocated quotas. Membership in SADSTIA included all the major players in the deep-trawl industry at that time, but it did not include two groups of smaller quota holders. And although the MSC certification covered the entire fishery, only fish processed and sold by members of the client group could bear the MSC logo. In other words, even within the bounded (but porous) space of South Africa's EEZ waters, boundaries are erected between subjects that 
are certified as acting sustainably and those that are not. This internal boundary setting was deliberate: during the two year evaluation process leading to the first certification in 2004 , the two or three large companies who were driving the certification process within SADISTIA sought to defend their quota allocation from further erosion to other trawling companies and to longliners, arguing that more players would work against proper fishery management and thus sustainability certification (Ponte, 2008). In the second certification of 2010, however, both SADSTIA and second association (SECIFA) were identified as 'clients', thus redefining the boundaries of those who could be considered a 'sustainable' subject.

Formally, the main object of MSC certification is the hake stock caught by trawlers; longline and handline fisheries are excluded. In fact the definition of this object is even more complicated because there are two species of hake caught in South African waters: Merluccius paradoxus and Merluccius capensis. The former is mainly caught by deep-sea trawlers, but also by longliners who are excluded from certification; the latter is caught mainly by inshore trawlers and the handline sector. MCM does not distinguish between the two species in their overall TAC allocation, although recent efforts have been directed at assessing the two stocks separately. The 2004 certification assessed the status of two stocks jointly, by giving it one overall score - even though the M. paradoxus stock was estimated to be at risk, while the $M$. capensis stock was thought to be in good condition. In the 2010 report on the second MSC certification, the two stocks were evaluated and scored separately, thus defining a boundary between two distinct objects of concern for the purpose of stock assessment. In both 2004 and 2010, ecosystem impacts and fishery management systems were scored jointly for the two species. Other objects of concern have been by-catch species and the marine eco-system impacted by the trawl fishery, including seabirds whose mortality needs to be minimised. 
MCM also provided key expertise and knowledge for obtaining certification. The expertise required for MSC certification more broadly is bounded - socio-economic conditions of fish capture and processing are excluded from the MSC standards, unlike the certification systems for aquaculture outlined above. Within this restricted field, a number of very different aspects are covered. Addressing the conditions attached to the 2004 certification, for example, entailed drawing on science and fishery management expertise to create a new by-catch management plan, improve the modeling of stock assessments (and linking it to a new model of ecosystem impact), and improve the assessment of the impacts on benthic habitat and on seabird populations. Much of this expertise was provided by or through MCM.

Assembling a sustainability territory: dynamics and outcomes

In MSC certification of South African hake, the assembling of sustainability territory took place through a complex overlap of boundary work and strong public regulatory authority. Only some objects were defined as significant within the porous sustainability space delimited by the national EEZ. Subject boundary work defined and redefined who could be deemed a 'sustainable' operator and who could not, and in relation to what objects of concern. The certification process itself involved the mobilization of bounded fields of expertise in fishery management, stock assessment and ecosystem impacts. MCM, a government agency, played a central role in obtaining and maintaining MSC certification, and thus in assembling a sustainable territory - as it manages hake quota allocations, provides much of the data needed for certification purposes, monitors compliance with a variety of regulatory measures, and operates a surveillance system. Among the four case studies, this is where state authority was most clearly employed in the process of assembling a (national) sustainable territory, and where it reasserted itself through a market-based mechanism. 


\subsection{MSC certification of skipjack tuna in the Western Pacific}

\section{Background}

The free school skip jack purse-seine fishery in the Western Pacific Ocean, is potentially the largest fishery ever certified by the MSC both by volume and value. The certification process, completed in 2011, is novel for two reasons. First, it was the first certification to acknowledge the potential sustainability purse seine fisheries not setting nets on floating fish attraction devices, that are widely acknowledged to have a negative impact on endangered and threatened species, such as false killer whales and whale sharks, and non-target tuna species such as the currently overfished bigeye tuna (Dagorn et al. 2013). Second, the client for the certification is the secretariat to the eight member countries ${ }^{7}$ of the Parties to the Nauru Agreement (PNA), a subregional fisheries management body established in 1982.

The certification has played an important role in supporting cooperation for sub-regional trans-boundary management, as well as giving greater credibility to the PNA's capacity for producing conservation and management measures for the EEZs of members states that have subsequently been taken up by the broader scale Western and Central Pacific Fisheries Commission (WCPFC) (Miller et al. 2014), including the extension of management control into interstitial high seas pockets (Campling and Havice 2014). The certification also adds market value to the PNA free-school skipjack tuna, connecting the PNA to powerful external markets

\footnotetext{
${ }^{7}$ PNA Members are Federated States of Micronesia, Kiribati, Marshall Islands, Nauru, Palau, Papua New Guinea, Solomon Islands and Tuvalu. For more information see http://www.pnatuna.com/About-Us\#sthash.fEDIdfDq.dpuf.
} 
like the EU and the US, and potentially strengthening member countries' economic control over tuna resources should a large enough proportion of the fishing vessels choose to participate.

(Re)defining space, subject, object and expertise through boundary work

MSC certification of so called 'free school' skipjack tuna purse seining in the Western Pacific has in principle established the largest certified space in the world. However, in practice, the specific space associated with the certification is assembled in three ways. First, it is only the free school tuna purse seine 'sets' that are certified, meaning that the overall area under the jurisdiction of the PNA resembles a fluid set of sustainable places defined the deployment of a specific fishing method (cf. Bush and Mol 2014). Second, under the 2010 Kokor declaration, a series of implementing measures that contributed to the MSC certification were introduced, including conditional access licenses for distant water vessels to waters within the PNA EEZ by closing access to two interstitial high seas pockets (see Havice 2013). Demonstrating that this measure, along with a series of others, including a vessel day scheme and $100 \%$ observer coverage, has allowed the PNA to extend the spatial boundary under control by the PNA members over the tuna fishery to high seas. In doing so therefore presents a sub-regional spatio-legal challenge to the juridical control exercised by the Western and Central Pacific Fisheries Commission (WCPFC) established in 2004 under the United Nations Convention on the Law of the Sea.

The main subjects of MSC certification are the vessels allowed to fish in the waters of the eight countries of the PNA, as well as the companies enrolled in chain-of-custody certification, and the Dutch company who is a 50-percent partner in the 'Pacifical' brand under which this tuna is traded (see Miller and Bush, 2014). Two classifications of vessels are enrolled into the certification: vessels who are flagged to the coastal states and distant-water vessels. Ultimately, however, each vessel chooses whether to set a net, if that set will comply with the requirements 
of the MSC certification, and therefore whether the fish caught will be traded as MSC-certified. This means that on any given fishing trip, a vessel can switch between including and excluding themselves from the certified space on a 'set-by-set' basis, meaning that the vessel itself carried both MSC-certified and non-certified skipjack tuna.

The objects of concern are principally the endangered and threatened species and non-target overfished bigeye tuna species associated with catches by purse seines setting nets on floating 'fish attraction devices' (FADs) - remotely monitored man-made floating objects that attract pelagic species enabling them to be efficiently harvested (Dempster and Taquet, 2004). Although purse-seine fisheries target stocks of skipjack tuna that are not subject to overfishing, the higher association of juvenile bigeye around FADs associated catch compared to free swimming schools of skipjack the focus of international concern (Bromhead et al., 2003). . The implementing measures of the PNA, on which the MSC certification of skipjack purse-seining is based, thus focus in large part on the use and management of these FADs (PNA, 2010).

The formulation of the PNA measures has set a new agenda for the development of conservation and management measures in the western Pacific Ocean, which requires new expertise and knowledge. The certified management measures are part of a wider process of innovation that has reframed 'free school' or 'FAD-free' fishing as a new definition of sustainability, and put in place some of the most advanced monitoring systems in the world (Havice, 2013; Miller and Bush, 2014). This led to considerable opposition from a number of organisations, notably purse seine-related groups such as the International Seafood Sustainability Foundation (ISSF) - an entity that has set private standards for 24 fishing and processing companies that are members of the International Seafood Sustainability Association fishing. These innovations are in part led by the private sector but to a great extent dependent on existing 
state support from the Fishery Forum Agency (FFA) for the design of new management measures, and the South Pacific Commission (SPC) responsible for all stock assessments in the region.

\section{Assembling a sustainability territory: dynamics and outcomes}

The MSC has not driven the territorialisation of access and control free school purse seine fisheries. But it has been key in providing credibility for the measures that the PNA has put in place, including the redefining sustainable fishing practices through the creation of sustainable territories both within and beyond their area of national jurisdiction. Indeed, the high level of resistance that the certification of the fishery received from those with a strong economic interest in FAD purse seine fisheries, as well as those maintaining regional access through the WCPFC, indicates the potential impact of the new territorial configuration that is emerging (see Banks et al. 2011). In short, the PNA measures can thus be seen as an attempt by coastal states to leverage greater value from tuna catches from their waters (through the 14 percent price premium guaranteed by Pacifical), and to place the more powerful fishing nations of the WCFPC under greater surveillance and monitoring, including even greater authority over their exclusion from the high-sea pockets (Havice, 2013). In doing so, the MSC stands to create a redistribution of power and control in the region in favour of a sub-set of small nations within the Pacific.

However, as noted by Miller et al. (2014), the stakes remain high: should economic benefits not accrue to the PNA states, it remains unclear whether MSC certification offers a long term means consolidating cooperation between these members states.

\section{Discussion and conclusions}


The four case studies examined above show how the assembling of sustainability territories through boundary work is a complex undertaking, and involves definitions and redefinitions of space, subjects, objects and expertise. It generates controversies and has important inclusion/exclusion consequences and distributional effects (see Table 1). Our analysis of these case studies suggests four main conclusions that relate to the debates highlighted in the first part of the article.

\section{TABLE 1 HERE}

First, assembling sustainability territories does not necessarily lead to a 'green grab'. The dynamics summarised in Table 1 do suggest a need to be aware of the overlapping dimensions and formats of inclusion/exclusion and redistribution, but only in the case of South African hake do we observe elements of the type of green grabbing mooted in the literature - here, MSC certification has provided an indirect tool against the possibility of further re-allocation of quotas away from the major fishing companies. The two cases on aquaculture highlight how farmers can be caught in the cross-fire between boundaries set by government regulation and by private standards (as in Vietnam), and that most problematic boundary issues often play out locally quite independently from sustainability certification (as in Thailand). Finally, the PNA tuna case study actually suggests that 'green grabbing' can be used to the benefit of weaker nations or players. Although these are diverse cases, all of them refer in some way to a private 'grab' of authority to create and enforce rules intended to protect environments. But unlike the literature to date, this does not necessarily imply a displacement of people from a territory. Instead it shows how subjects are required to comply with in situ rules on ecological interaction, and how people themselves become objects of concern and protection (when social standards are in place). 
Second, sustainable territories are not assembled in a vacuum. Although by facilitating control between topographically distant places certification attempts to homogenise the territories created (Bear and Eden 2008), it also draws on and is in turn subject to existing spaces, subjects and objects. The re-definition of the territorial assemblages is therefore in many ways also embedded in the networks it seeks to create. In Thailand, an existing and relatively simple definition of farm boundaries has become far more complex with sustainability certification through the addition of buffer zones, other ecological criteria, community consultation, and processor-sponsored group certifications. In Vietnam, space also became redefined through a complex overlap of nested layers. In South Africa, the spatial boundary remained set in the existing EEZ, but objects of concerns move in and out of it. In the case of PNA tuna, the space of jurisdiction was actually extended through certification to international waters. Boundaries around subjects also become more blurred with certification, as in the case of Vietnam. They can change between one certification process and the next (as in South Africa) and include combinations of public and private actors (as in the PNA). But perhaps the clearest boundary work takes place in relation to objects of concern, which are almost inevitably redefined, multiplied and reframed.

Third, boundary work is tightly linked to an entire apparatus of expertise and knowledge. Experts define objects of concern are produced through the definition of standards, and in turn these standards reproduce and reify these objects of concern by making them legible and therefore 'seen' by another set of experts - the auditors. At the same time, some objects (e.g. a 'collective' mangrove cover; workers' labour conditions on trawlers) do not make it into the standards because they are difficult or controversial to audit, and/or because some interest groups worked against (and continue to work against) their inclusion in the standards. Specific expertise 
is demanded and barriers erected through the accreditation of those actors that are used by standards-holding bodies to undertake assessment. In doing so, a multi-billion dollar industry is being creating that undertakes assessments, auditing, and consulting services to help clients become audit-ready. As certification concentrates capacities to produce knowledge and mobilise action, other (often local) expertise and knowledge brokers are marginalised from the production of relevant ecological and social knowledge. For small-scale aquaculture, for example, these might include not only the obvious local communities (fishers, farmers, gardeners, water users, etc), but also local government units, NGOs and local activists who may be active in coastal zone conservation, and market intermediaries who often act as important nodes in the movement of various kinds of knowledge (also see Kusumawati et al., 2013). Although many certifications involve some kind of process for consulting surrounding communities, the production of expertise counters these provisions by isolating the certified territory from the surrounding landscape and people. At the same time, the case of the PNA shows that boundary work can also create progressive change by challenging hegemonic expertise and its related knowledge.

Fourth, there is considerable variation in how state agencies have responded to the nongovernmental re-assembling of territoriality and the seizing of authority. While some agencies have been suspicious of transnational or 'private' sustainability certification, others have embraced it or even used it to extend their sovereignty for reasons that have little to do with commodification. In Vietnam, certification became a means for reinforcing state territorialisation, including the jurisdiction of the state forestry company, and regulations regarding farm management. The PNA member states used MSC certification to extend their territorial claims by extending claims over specific fishing practices that extend beyond areas of national jurisdiction.. Much depends on how a sustainability certification scheme is designed. MSC, for example, has 
not promoted itself as an alternative to state management. It assesses existing fisheries management regimes, which have their own defined boundaries, which in practice often means government bodies and government-defined fisheries. Thus unlike aquaculture certification, it is not possible for the MSC to operate in pure competition with government fishery management agencies. Sustainability certification has facilitated a partial 'outsourcing' of some elements of state regulation (setting standards, fishery assessments) to private players, but at the same time creates sustainability space on the basis of state territorialisations. Certification by the MSC can actually provide positive legitimation effects for state management agencies that have been labeled as failures in their management of fisheries. And MSC certification processes can attract donor funding to government agencies, especially in the Global South. Not all states, however, are willing to turn to private regulation, despite these advantages. Some governments have questioned whether private bodies should be involved in fisheries management (Foley 2013: 291), and supported the development of state-level sustainability certification programs (e.g. Foley and Hébert, 2013; Kvalvik et al., 2014).

Together these conclusions point to the need for rethinking the role of public and private authority in assembling sustainability territories through certification. Certification can indeed lead to a redefinition of territorial sovereignty and a renegotiation of power within national and transnational spaces, but not necessarily in the direction of 'green grabbing'. By providing a more nuanced understanding of certification as made up of multiple logics including but also beyond the market we showed that different forms of exclusion and commodification arise from different ways in which sustainability territories are assembled. Boundaries over space, subjects, objects and expertise are (re)shaped by competitive, complimentary and/or parallel processes led by various configurations of state and private actors. Future research is thus needed to assess, in 
seafood industries and beyond, how sustainable territories are actually assembled, by whom, and with what consequences - in view of informing policy and practice .

\section{References}

Auld G, Balboa C, Bernstein S, Cashore B, Delmas M, Young O, 2009, "The emergence of nonstate market-driven (NSDM) global environmental governance" Governance for the Environment: New Perspectives 183

Banks, R, Clark L, Huntington T, Lewis T, Hough A (2011) MSC Assessment Report for PNA Western and Central Pacific Skipjack Tuna (Katsuwonus pelamis) unassociated and log set purse seine fishery. Version: 5 Public Certification Report Ref: 82122/v5. Moody Marine, Derby.

Bear C, Eden S, 2008, "Making space for fish: the regional, network and fluid spaces of fisheries certification" Social \& Cultural Geography 9 487-504

Béné C, 2005, "The good, the bad and the ugly" Development Policy Review 23 585-614

Bowen, S. (2011). The Importance of Place: Re - territorialising Embeddedness. Sociologia

Ruralis, 51(4), 325-348.

Bridge, G. (2011). Resource geographies 1 Making carbon economies, old and new. Progress in Human Geography, 35(6), 820-834.

Bromhead D, Foster J, Attard R, Findlay J, Kalish J, 2003, "A Review of the Impact of FADs on Tuna Fisheries: Final Report to Fisheries Resources Research Fund", (Commonwealth Department of Agriculture, Fisheries and Forestry, Australia.) 
Brummett R E, 2013, "Growing Aquaculture in Sustainable Ecosystems", (World Bank, Washington)

Bush S R, Belton B, Hall D, Vandergeest P, Murray F J, Ponte S, Oosterveer P, Islam M S, Mol A P J, Hatanaka M, Kruijssen F, Ha T T T, Little D C, Kusumawati R, 2013, "Certify Sustainable Aquaculture?" Science 341 1067-1068

Bush S R, Van Zwieten P A M, Visser L, Van Dijk H, Bosma R, De Boer W F, Verdegem M, 2010, "Scenarios for resilient shrimp aquaculture in tropical coastal areas" Ecology and Society 15 15. [online] URL: http://www.ecologyandsociety.org/vol15/iss12/art15/

Bush, S. R., \& Mol, A. P. (2014). "Governing in a placeless environment: Sustainability and fish aggregating devices". Environmental Science \& Policy doi:10.1016/j.envsci.2014.07.016

Campling, L., \& Havice, E. (2014). The problem of property in industrial fisheries. Journal of Peasant Studies 1-21. DOI: 10.1080/03066150.2014.894909

Cashore B, Auld G, Newsom D, 2004 Governing Through Markets: Forest Certification and the Emergence of Non-State Authority (Yale University Press, New Haven and London)

Corson C, 2011, "Territorialization, enclosure and neoliberalism: non-state influence in struggles over Madagascar's forests" Journal of Peasant Studies 38 703-726

Corson C, MacDonald K, Neimark B, 2013, "Grabbing “green”: Markets, environmental governance, and the materialization of natural capital" Human Geography 6 1-15

Dagorn, L., Holland, K. N., Restrepo, V., \& Moreno, G. (2013). Is it good or bad to fish with FADs? What are the real impacts of the use of drifting FADs on pelagic marine ecosystems?. Fish and Fisheries, 14(3), 391-415. 
Dempster T, Taquet M, 2004, "Fish aggregation device (FAD) research: gaps in current knowledge and future directions for ecological studies" Reviews in Fish Biology and Fisheries 14 $21-42$

Eden S, 2009, "The work of environmental governance networks: Traceability, credibility and certification by the Forest Stewardship Council" Geoforum 40 383-394

Fairhead J, Leach M, Scoones I, 2012, "Green grabbing: a new appropriation of nature?" Journal of Peasant Studies 39 237-261

FAO, 2012, "The State of World Fisheries and Aquaculture ", (FAO Fisheries and Aquaculture Department, Food and Agriculture Organization of the United Nations, Rome)

Foley P, 2012a, "The political economy of Marine Stewardship Council certification: Processors and access in Newfoundland and Labrador's inshore shrimp industry" Journal of Agrarian Change 12 436-457

Foley P, 2013, "National government responses to Marine Stewardship Council (MSC) fisheries certification: insights from Atlantic Canada" New Political Economy 18 284-307

Foley P, Hébert K, 2013, "Alternative regimes of transnational environmental certification: governance, marketization, and place in Alaska's salmon fisheries" Environment and Planning A 45 2734-2751

Gibbon, P, Ponte S, 2005, Trading Down: Africa, Value Chains and the Global Economy. Temple University Press: Philadelphia

Gulbrandsen L H, 2013, "Dynamic governance interactions: Evolutionary effects of state responses to non - state certification programs" Regulation \& Governance 8 74-92 
Ha T T T, 2012 Global and local governance of shrimp farming in the Mekong Delta, Vietnam, Wageningen University, Wageningen

Ha T T T, Bush S R, Mol A P J, Van Dijk H, 2012, "Organic coasts? Regulatory challenges of certifying integrated shrimp-mangrove production systems in Vietnam" The Journal of Rural Studies 28 631-639

Hanich Q, 2012, "Distributing the bigeye conservation burden in the western and central pacific fisheries" Marine Policy 36 327-332

Hatanaka M, 2010, "Certification, Partnership, and Morality in an Organic Shrimp Network: Rethinking Transnational Alternative Agrifood Networks" World Development 38 706-716 Hatanaka M, Bain C, Busch L, 2005, "Third-party certification in the global agrifood system" Food Policy 30 354-369

Havice E, 2013, "Rights-based management in the Western and Central Pacific Ocean tuna fishery: Economic and environmental change under the Vessel Day Scheme" Marine Policy 42 $259-267$

Higgins V, Dibden J, Cocklin C, 2008, "Building alternative agri-food networks: Certification, embeddedness and agri-environmental governance" Journal of Rural Studies 24 15-27

Klooster D, 2005, "Environmental certification of forests: The evolution of environmental governance in a commodity network" Journal of Rural Studies 21 403-417

Konefal J, 2010, "Food, the Environment, and Democracy: A Case Study of the Marine Conservation Movement's Shift from State-Centered to Market-Based Approaches" Journal of Rural Social Sciences 25 226-252 
Konefal J, 2013, "Environmental Movements, Market-Based Approaches, and Neoliberalization A Case Study of the Sustainable Seafood Movement" Organization \& Environment 26 336-352 Kusumawati R, Bush S R, Visser L, 2013, "Can patrons be by-passed? Frictions between local and global regulatory networks over shrimp aquaculture in East Kalimantan" Society and Natural Resources 26898 - 911

Kvalvik I, Noestvold B H, Young J A, 2014, "National or supranational fisheries sustainability certification schemes? A critical analysis of Norwegian and Icelandic responses" Marine Policy $46137-142$

Langley A, Wright A, Hurry G, Hampton J, Aqorua T, Rodwell L, 2009, "Slow steps towards management of the world's largest tuna fishery" Marine Policy 33 271-279

Lebel L, Mungkung R, Gheewala S H, Lebel P, 2010, "Innovation cycles, niches and sustainability in the shrimp aquaculture industry in Thailand" Environmental Science \& Policy 13 291-302

MacDonald K, 2013, "Grabbing Green: Cynical Reason, Instrumental Ethics and the Production of "The Green Economy'"' Human Geography 6 46-63

Miller A M, Bush S R, 2014, "Authority without credibility? Competition and conflict between ecolabels in tuna fisheries" Journal of Cleaner Production Mitchell T, 2002 Rule of experts: Egypt, techno-politics, modernity (Univ of California Press) Mutersbaugh T, 2005, "Fighting standards with standards: harmonization, rents, and social accountability in certified agrofood networks" Environment and Planning A 37 2033-2051 
Mutersbaugh T, Lyon S, 2010, "Transparency and democracy in certified ethical commodity networks" Geoforum 41 27-32

Naylor R L, Hardy R W, Bureau D P, Chiu A, Elliott M, Farrell A P, Forster I, Gatlin D M, Goldburg R J, Hua K, Nichols P D, 2009, "Feeding aquaculture in an era of finite resources" Proceedings of the National Academy of Sciences 106 15103-15110

Omoto R, 2012 Small-scale producers and the governance of certified organic seafood production in Vietnam's Mekong Delta, Department of Geography, University of Waterloo, Waterloo

Painter J, 2010, "Rethinking territory" Antipode 42 1090-1118

Parkes G, Young J A, Walmsley S F, Abel R, Harman J, Horvat P, Lem A, MacFarlane A, Mens M, Nolan C, 2010, "Behind the Signs_-A Global Review of Fish Sustainability Information Schemes" Reviews in Fisheries Science 18344 - 356

Peluso N L, Vandergeest P, 2001, "Genealogies of the political forest and customary rights in Indonesia, Malaysia, and Thailand" Journal of Asian Studies 60 761-812

PNA, 2010, "A third arrangement implementing the Nauru Agreement setting forth additional terms and conditions of access to the fisheries zones of the parties", Ed Parties to the Nauru Agreement (Koror, Palau)

Ponte S, 2008, "Greener than Thou: The Political Economy of Fish Ecolabeling and Its Local Manifestations in South Africa" World Development 36 159-175

Ponte S, 2012, "The Marine Stewardship Council (MSC) and the Making of a Market for 'Sustainable Fish'" Journal of Agrarian Change 12 300-315 
Ramirez Cover A, 2013, "Uneven territorialization and sea turtle conservation in neoliberal Costa Rica" Human Geography 6 151-165

Sikor T, Lund C, 2009, "Access and property: a question of power and authority" Development and Change $\mathbf{4 0}$ 1-22

Vandergeest P, 2007, "Certification and Communities: Alternatives for Regulating the Environmental and Social Impacts of Shrimp Farming" World Development 35 1152-1171

Vandergeest P, Peluso N L, 1995, "Territorialization and state power in Thailand" Theory and society $24385-426$

Vandergeest P, Unno A, 2012, "A new extraterritoriality? Aquaculture certification, sovereignty, and empire" Political Geography 31 358-367 
Table 1: Main features of assembling sustainable territories in the four case studies

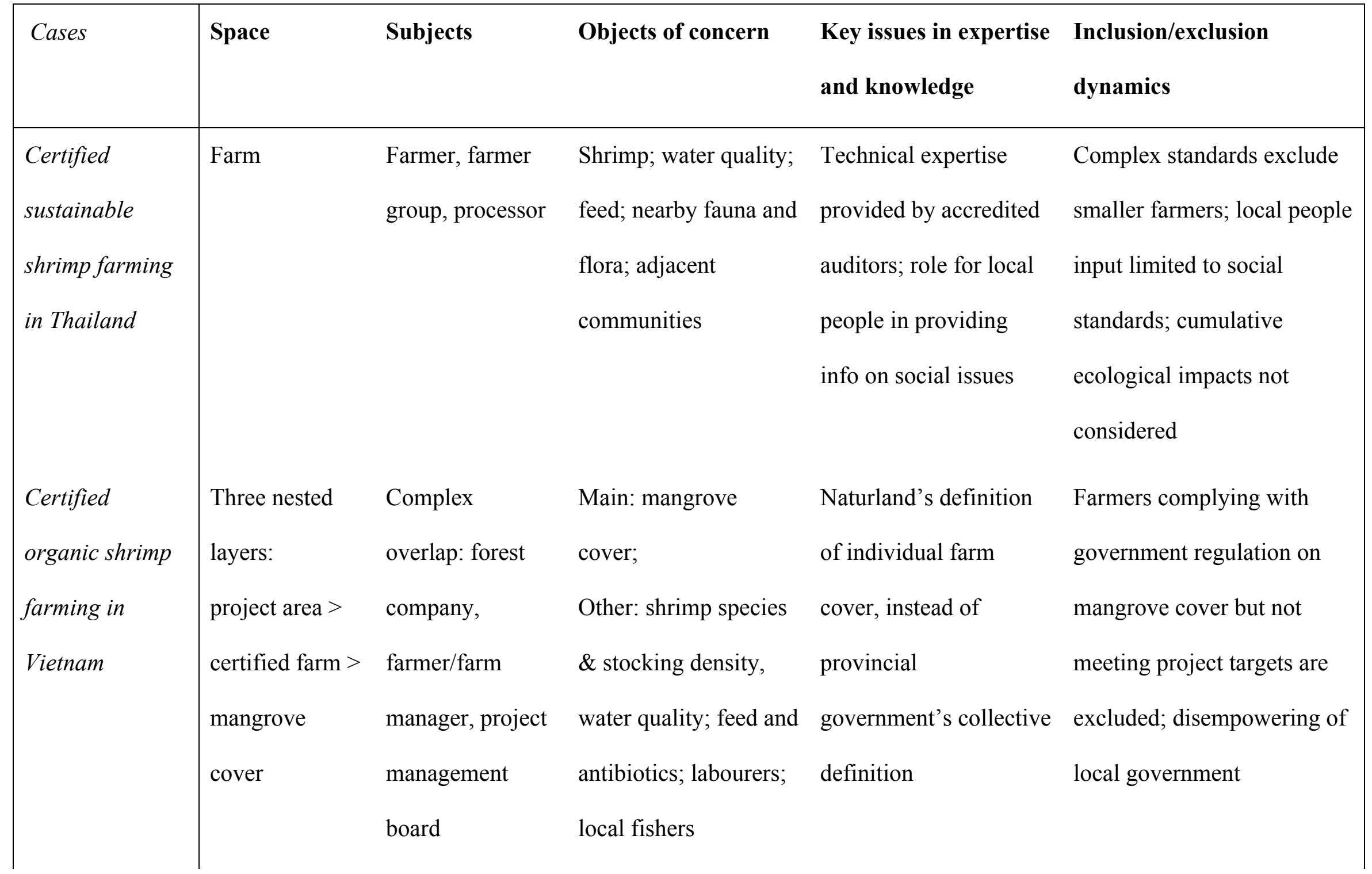




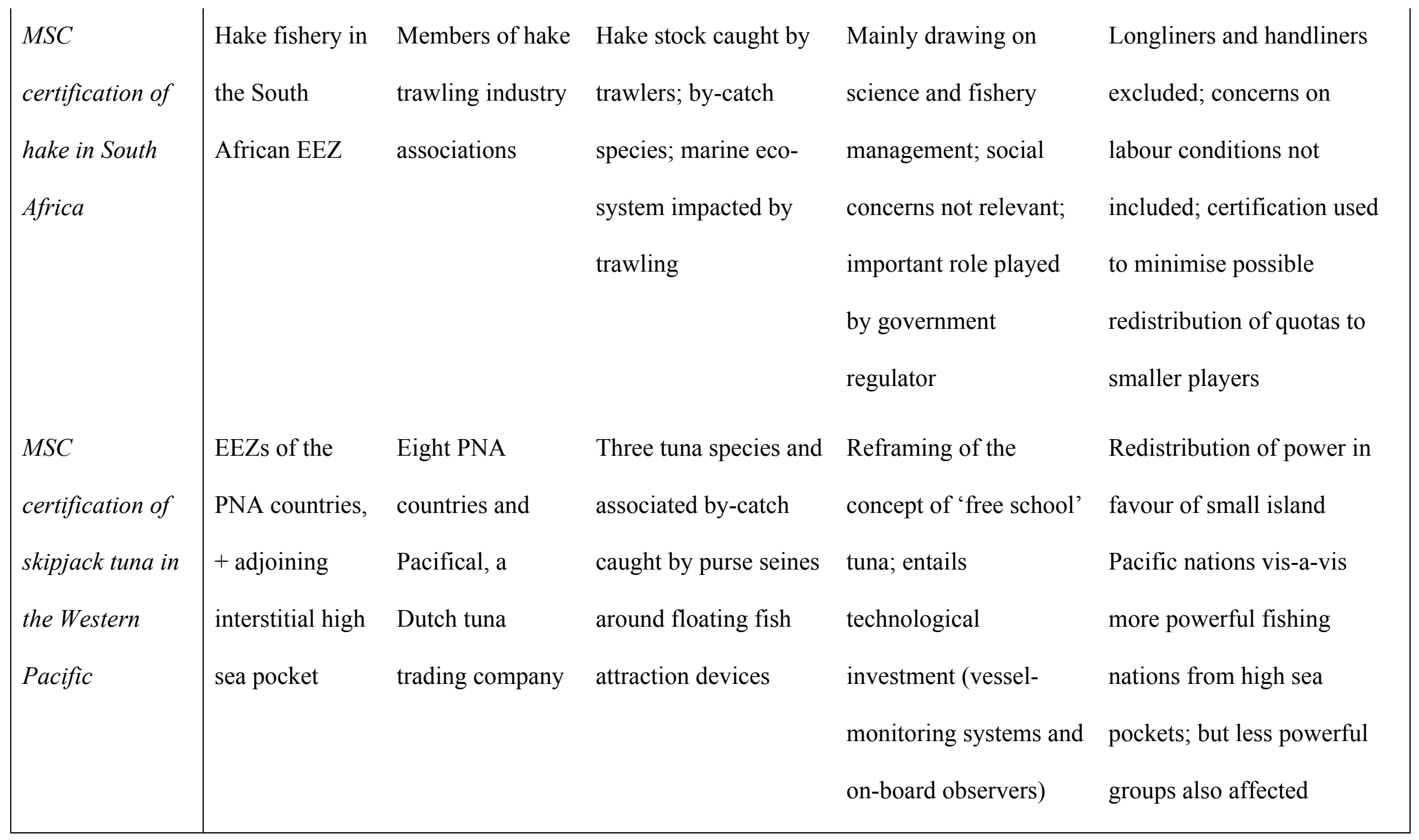

